\title{
EXPERIMENTAL SALMONELLA GALLINARUM INFECTION IN LIGHT LAYING HEN LINES
}

\author{
Angelo Berchieri Júnior ${ }^{1 *}$; Gláucia Helaine de Oliveira ${ }^{1}$; Lucas Augusto Soeiro Pinheiro ${ }^{1}$ Paul A. Barrow ${ }^{2}$ \\ ${ }^{1}$ Faculdade de Ciências Agrárias e Veterinárias, Universidade Estadual Paulista, Jaboticabal, SP, Brasil. ${ }^{2}$ Division of \\ Environmental Microbiology, Institute for Animal Health, Compton Laboratory, Compton, Newbury, Berkshire, United \\ Kingdom.
}

Submitted: December 04, 1998; Returned to authors for corrections: May 25, 1999; Approved: March 22, 2000

\begin{abstract}
Although the epidemiology of fowl typhoid in chickens supposedly involves a vertical transmission stage, a previous work run by the authors has suggested that this did not happen in a commercial line of laying hens highly susceptible to systemic disease with Salmonella Gallinarum. A new experiment was carried out in two other lines of commercial layers, considerably more resistant than those used in the previous study. Clinical fowl typhoid was not observed, but Salmonella Gallinarum was isolated from the spleen and liver four weeks after infection and, sporadically, from the ovary.
\end{abstract}

Key words: Salmonella Gallinarum, White Leghorn, infection, laying hens

Fowl typhoid remains a serious systemic disease of domestic poultry which may cause large scale economic losses through mortality, morbidity and reduction in egg production. The disease is under control in many countries in Europe and North America but remains a major problem in countries where poultry husbandry was recently intensified or where the high ambient temperature causes difficulties to environmental hygiene. Even in countries where the disease is controlled, vigilance remains important. The injudicious introduction of infected poultry has led to local national resurgence of the disease in northern Europe (10). Although the epidemiology of fowl typhoid has been well documented in the literature over the years, the relative contribution of horizontal and vertical transmissions remains unclear. Experimental work has shown that the infection may spread horizontally between pen mates $(6,12)$ and reports of vertical transmission were made several decades ago $(3,4,5)$. There have been numerous reports of isolation of $S$. Gallinarum from the eggs of reactor birds $(14,15,16)$ but much less information is available on direct evidence of transmission of the pathogen through eggs to the progeny. Hall et al. (13) found that $50 \%$ of typhoid reactors, infected either naturally or experimentally, produced infected eggs which resulted in infected chicks. A high percentage of these chickens (33\%) died within six months; most died within the first month.

In a recent preliminary investigation on persistent infection of laying hens by Salmonella Gallinarum, $S$. Pullorum and $S$. Enteritidis it was found difficult to establish long lasting infections in young or adult commercial laying hens (7). Birds either succumbed to clinical disease or did not become infected. The evidence from the literature indicates that vertical transmission is associated with persistent infection in the absence of clinical disease. The commercial birds used in that preliminary investigation were highly susceptible to infection by this serotype. Therefore, the authors considered that more positive results may follow infection of a more resistant light line of hen. The present report describes the results of infection of

\footnotetext{
* Corresponding author. Mailing address: Faculdade de Ciências Agrárias e Veterinárias, UNESP, CEP 14870-000, Jaboticabal, SP, Brasil. E-mail: berchier@fcav.unesp.br
} 
commercial layers belonging to a light breed with increased level of resistance to $S$. Gallinarum infection.

Two lines of commercial white laying hens (White Leghorn), which produce light-coloured white eggs, were used in this experiment. Birds from Hy-Line line were 44 weeks old and birds from Babcock line were 46 weeks old. All birds were laying when the experiment started. A commercial layer feed was provided by the farmer.

The birds were kept in individual wire cages to allow laying to continue. Cloacal swabs and blood samples for bacteriological and serological examination were taken to assess that birds were free of Salmonella before starting the experiment. Cloacal swabs were done as shown below. The samples of sera were submitted to slide agglutination test using a commercial pullorum antigen and also a overnight growth of $S$. Gallinarum on Brain Heart Infusion Agar (BHI agar). The birds were allowed to settle for three days before starting the experiment. The birds were numbered from 01 to 21 (Hy-Line) and 22 to 42 (Babcock). A broth culture of a nalidixic acid resistant mutant of $S$. Gallinarum $9(2,17)$, prepared in Brain Heart Infusion broth (BHI broth) and incubated overnight at $37^{\circ} \mathrm{C}$ in a shaking incubator, was prepared and diluted in BHI broth to contain $1.5 \times 10^{7}$ viable cells per ml. From this, $0.5 \mathrm{ml}$ was orally inoculated into the crop of each bird. Three birds from each line were killed for post-mortem examination at 1, 3, 7, 14, 21 and 28 days after inoculation.

During necropsy, samples from liver, spleen, ovary, caecal contents, cloacae and blood were collected. All eggs found inside the oviduct were examined too. The blood samples were used for serological analysis and the other samples were investigated bacteriologically. Twice a week a cloacal swab was taken from all live birds. All eggs laid were inspected to Salmonella.

The bacteriological examination followed the methodology adopted previously by Barrow et al. (1). After opening the carcass, organs were removed aseptically in this order: ovary, spleen, liver, egg in oviduct and caeca. Samples from liver, spleen and caecal contents were homogenised with a Griffith's tube and decimal dilutions were prepared in PBS, $\mathrm{pH}$ 7.4. Viable counts were estimated by plating aliquots of dilutions on Brilliant Green agar containing $25 \mathrm{ug} / \mathrm{ml}$ of nalidixic acid and $2 \mathrm{ug} / \mathrm{ml}$ of novobiocin (BGNal/Nov). The plates were incubated at $42^{\circ} \mathrm{C}$ overnight. When there was no bacterial growth, an equal volume of double strength selenite broth was added to the sample. After overnight incubation at $42^{\circ} \mathrm{C}$, the broth was streaked on $\mathrm{BG} \mathrm{Nal} / \mathrm{Nov}$. Cloacal swabs were placed in a tube containing $2 \mathrm{ml}$ of selenite broth. After mixing, this broth was plated on BG Nal/Nov and the swabs in broth were incubated at $42^{\circ} \mathrm{C}$ overnight. If no growth of Salmonella was obtained by direct plating, the overnight-enriched culture was plated in a similar manner. The ovary was added to $100 \mathrm{ml}$ of selenite broth in a sterile jar, followed by gross maceration with sterile scissors. The jar was incubated at $42^{\circ} \mathrm{C}$ overnight and the cultures were plated as mentioned above.
The sera from the blood samples were tested for agglutination on a glass slide with overnight growth of $S$. Gallinarum on BHI agar.

On arrival, bacteriological and serological examination of the birds did not reveal any evidence of Salmonella infection.

The results of the microbiological examination of the birds are presented in Table 1. Following oral inoculation of Salmonella Gallinarum $9 \mathrm{Nal}^{\mathrm{r}}$, the bacterium was not isolated one day post infection but was detected in the liver and spleen of $3 / 6$ birds four days post-inoculation, and in the cloaca of one bird after enrichment. Similar results were found in $4 / 6$ birds after one week. The number of bacteria in the tissues had such a decrease that isolations were successful (after enrichment only) in $4 / 6$ birds only after 2 weeks, and $2 / 6$ only after 4 weeks. Isolations from the ovary were obtained after one and two weeks of inoculation. Over a post inoculation period of 34 days, Hyline birds laid 253 eggs and Babcock birds laid 201 eggs. Salmonella was not isolated from these eggs.

At necropsy, typical fowl typhoid-like alterations were seen in the liver and spleen of several birds. After infection, the following was observed: three days post-inoculation (dpi), birds 16 and 37 presented enlarged and congested liver and hemorrhagic ovary follicles; 7 dpi: birds 14, 15, 35 and 36 presented fowl typhoid-like alterations; $14 \mathrm{dpi}$ : bird 32 presented ovary atrophy and 33 presented fowl typhoid like alterations; 21 dpi : birds 7, 8, 29 and 30 with fowl typhoid-like lesions. The main fowl typhoidlike lesions were enlarged liver and spleen with necrotic and hemorrhagic points and green-yellowish liver colour. Typical changes in the structure of the ovaries were also seen. The diarrhoea was stronger for Hy-line than for Babcock birds. Both lines had a drop in egg production for 12 days from the fifth day after infection. However, in contrast to two susceptible line of birds also infected with $S$. Gallinarum in a similar study, there was no progress in the illness and no mortality was noticed. The assay using birds from susceptible lines demonstrated that the mortality is high and initiated 5-7 dpi. In those few remaining birds which did not develop the disease, $S$. Gallinarum was not isolated in samples taken from liver, spleen, ovary, heart and caecal contents (7). Thus, the result does suggest that lines of chicken genetically resistant to systemic salmonellosis may harbour the pathogen for several weeks. During this experiment the organism was not isolated from the laid eggs but it is possible that insufficient eggs were examined, although a figure of $6 \%$ of hatched eggs was mentioned by Hall et al. (13). The resistance seen by Bumstead and Barrow $(8,9)$, manifested by a difference in the rate at which the pathogen multiplied in the reticulo-endothelial system cells and the rate of decay in the tissues, was not involved since this could not, anyway, be measured. Thus, it is possible that whereas transmission of infection between birds may be primarily horizontal in susceptible lines due to ingestion of faeces and mucus containing $S$. Gallinarum and to cannibalism, vertical transmission is much more likely to occur in lines which are 
Table 1. Positivity for Salmonella Gallinarum infection in two white eggs laying hens (White Leghorn).

\begin{tabular}{|c|c|c|c|c|c|c|c|c|c|c|c|c|c|c|c|c|c|c|c|c|c|c|c|c|}
\hline \multirow[b]{2}{*}{ Bird number** } & \multicolumn{6}{|c|}{4 days* } & \multicolumn{6}{|c|}{1 week* $^{*}$} & \multicolumn{6}{|c|}{2 weeks* } & \multicolumn{6}{|c|}{4 weeks* } \\
\hline & 16 & 17 & 18 & 37 & 38 & 39 & 13 & 14 & 15 & 36 & 35 & 34 & 10 & 11 & 12 & 33 & 32 & 31 & 04 & 05 & 06 & 27 & 26 & 25 \\
\hline \multicolumn{25}{|l|}{ Collected sample } \\
\hline Spleen & $2.8 * * *$ & - & - & $3.0^{* * *}$ & $3.4^{* * *}$ & - & - & $2.5^{* * *}$ & $2.3^{* * *}$ & $2.9^{* * *}$ & $3.2 * * *$ & - & - & - & - & $+* * * *$ & - & - & - & - & $+* * * *$ & - & - & $+* * * *$ \\
\hline Ovary & - & - & - & - & $+* * * *$ & - & - & $+* * * *$ & - & - & $+* * * *$ & - & $+* * * *$ & $+* * * *$ & - & $+* * * *$ & - & - & - & - & - & - & - & - \\
\hline Caecal contents & - & - & - & - & - & - & - & - & - & - & - & - & - & - & - & - & - & - & - & - & - & - & - & - \\
\hline
\end{tabular}

* Killing time after inoculation with $S$. Gallinarum

** Birds 01 to 21 are Hy-line and 22 to 42 are Babcock

*** $\log 10$

**** Positive result after enrichment in selenite broth; na $=$ not available.

genetically resistant to clinical fowl typhoid. This has a number of implications for management and breeding of lines which are more resistant to clinical disease. The rate of destruction of Salmonella in the tissues of resistant birds may be increased by vaccination. There is some indication that killed vaccines, although not very effective in Salmonella-susceptible mouse lines, could be more effective in genetically resistant lines (11).

\section{ACKNOWLEDGEMENTS}

The authors wish to acknowledge Mr. A.J. dos Santos and Mrs. A. R. Batista for assistance in various ways and to thank CNPq and FAPESP for financial support.

\section{RESUMO}

\section{Infecção experimental por Salmonella Gallinarum de aves leves de postura comercial}

Estudo anterior, realizado pelos mesmos autores com aves consideradas susceptíveis ao agente do tifo aviário, sugeriu que a relação entre a bactéria e a aves restringe-se ao período da enfermidade. Neste trabalho avaliou-se a relação hospedeiroparasita entre Salmonella Gallinarum e aves leves de postura comercial, consideradas mais resistentes ao tifo aviário. As aves não desenvolveram a doença clínica, mas a bactéria foi isolada do baço e do fígado quatro semanas após a infecção e, em algumas ocasiões, também do ovário.

Palavras-chave: Salmonella Gallinarum, White Leghorn, infecção, aves de postura

\section{REFERENCES}

1. Barrow, P.; Huggins, M.B.; Simpson, J.M.; Lovell, M.A. Observations on the pathogenesis of Salmonella typhimurium infection in chickens. Res. Vet. Sci., 42: 194-199, 1987.

2. Barrow, P.A.; Lovell, M.A.; Berchieri, A. Jr. The use of two live attenuated vaccines to immunize egg-laying hens against Salmonella enteritidis phage type 4. Avian Pathol., 20: 681-692, 1991.

3. Beach, J. R.; Davis, D. E. Acute infection in chicks and chronic infection of the ovaries of hens caused by the fowl typhoid organisms. Hilgardia, 2: 411-424, 1927.

4. Beaudette, F. R. The possible transmission of fowl typhoid through the egg. JAVMA, 67: 741-745, 1925.

5. Beaudette, F. R. Fowl typhoid and bacillary white diarrhoea. Proceedings of the $11^{\text {th }}$ International Veterinary Congress, 3: 705-723, 1930.

6. Berchieri Jr., A.; Barrow, P.A.. Reduction in incidence of experimental fowl typhoid by incorporation of a commercial formic acid preparation (Bio-Add ${ }^{\mathrm{TM}}$ ) into poultry feed. Poult. Sci., 75: 339-341, 1996.

7. Berchieri Jr., A.; Barrow, P.A.; Murphy, C. K. Vertical transmission of Salmonella gallinarum, S. pullorum and S. enteritidis in commercial brown-eggs layers. Salmonella and Salmonellosis Symposium, Ploufragan, France, 1997, p. 293-4.

8. Bumstead, N.; Barrow, P.A. Genetics of resistance to Salmonella typhimurium in newly hatched chicks. Br. Poult. Sci., 29: 521-529, 1988.

9. Bumstead, N.; Barrow, P.A. Resistance to Salmonella gallinarum, $S$. pullorum and $S$. enteritidis in inbred lines of chickens. Avian Dis., 37: 189-193, 1993.

10. Christensen, J. P.; Olsen, J. E.; Hansen, H. C.; Bisgaard, M. Characterization of Salmonella enterica serovar Gallinarum biovars gallinarum and pullorum by plasmid profiling and biochemical analysis. Avian Pathol., 21:461-470, 1992.

11. Collins, F. M. Vaccines and cell mediated immunity. Bacteriol. Rev., 38: 371-402, 1974.

12. Gorduek, S.; Glantz, P. J.; Callenbach, E. W.; Thorp, W. T. S. Transmission of fowl typhoid. Poult. Sci., 28: 385-391, 1949.

13. Hall, W. J.; Legenhausen, D. H.; MacDonald, A. D. Studies on fowl typhoid. 1. Nature and dissemination. Poult. Sci., 28: 344-362, 1949.

14. Jordan, F. T. W. The transmission of Salmonella gallinarum through the egg. Poult. Sci., 35: 1019-1025, 1956.

15. Moore, E. N. Fowl typhoid transmission. Delaware Agricultural Experimental Station Bulletin, 262: 21, 1946.

16. Rao, S. B. V.; Narayanan, S.; Ramnani, D. R.; Das, J. Avian salmonellosis: studies on Salmonella gallinarum. Indian J. Vet. Sci., 22: 199- 208, 1952.

17. Smith, H.W. The use of live vaccines in experimental Salmonella gallinarum infection in chickens with observations on their interference effect. J. Hyg, 54: 419-432, 1956. 